\title{
Strategic Partnership with High Growth Companies: Eligible Companies Selection Algorithm
}

\author{
Byl E.A.* Gamilova D.A. Sayfullina S.F. \\ Department of Economics and Management at the Oil and Gas Industry Enterprise, Ufa State Petroleum Technological \\ University, Ufa, Russian Federation \\ *Corresponding author. Email: ms.byl@mail.ru
}

\begin{abstract}
This article describes the algorithm of decision-making regarding the selection of eligible companies that meet the criteria of major industrial enterprises as raised for strategic partnership. The algorithm is based on stagewise dropout of companies based on the features allowing to rely on open data and to formalize expert assessment as much as possible. In the present article we have proposed the High Growth Companies' eligibility criteria, described the strategic partnership forms, a method for evaluating the most efficient form of HGC, as well as HGC selection mechanism that matches the initiating company's purposes.

Keywords: strategic partnership, companies selection algorithm, evaluation criteria, High-Growth
\end{abstract}

Companies

\section{INTRODUCTION}

Huge bulk data that are specific for current managerial situation call for clear processing algorithms, verifying reliability and sufficiency for decision - making.

Under the conditions of digital transformation, the use of trained machines to process data sets and prepare information for decision-making seems as the best outcome [1]. However, in fact, different types of solutions need their own procedures and alternatives selection criteria. In this situation, the preparation of decision-making algorithms that allow:

— Minimizing or formalizing expert participation;

— Using data from open and verified sources;

- Having a data sample that is sufficient by volume and variety for machine learning, are most topical.

This article deals with creating an algorithm for substantiating major industrial enterprises (MIE)'s decisions on establishing partnership relations with HighGrowth Companies for bridging technological development barriers.

The relevance of development problems is highlighted in the works of such distinguished economists as I.B. Sergeev, T.V. Ponomarenko, E.V. Pilipenko, K.P. Grinyuk, L.M. Grigoriev. The researchers express divergent opinions regarding mechanisms and tools of major industrial companies' development. A.A. Govorin argues that "new approaches in management of development economic systems" are more promising [2], while I.B. Sergeev prioritizes "high technologies that enable efficient use of resources" [3]. Meanwhile, all contemporary researchers share the view on the importance to take into account innovative technologies in the major industrial complex development strategies. O.K. Dorozhkina considers innovative strategies in enterprise development as one of the most important factors to achieve strategic advantages [4]. I. M. Stepnova defines high technologies and their development as a "driver of changes in industry" [5], while V.S. Litvinenko and I.B. Sergeev note that these technologies entail changes in the enterprises' strategic management process. [6,7].

Strategic partnership issues have been raised in the studies by R.L. Wallace, I.A. Kuznetsova, and M.L. Luchko. In most cases, a partner company was selected on the basis of expert assessments and ranking of the obtained indicators (D.Meister, N.Grankin) [8,9]. Scoring is one of the most popular systems to applied while evaluating enterprises (O. Shinkevich) [10]. While developing specific selection tools, qualitative and quantitative criteria have already been used, e.g. Yu. A Popova [11] suggests 4 quantitative and 10 qualitative parameters of evaluation be applied in the strategic management algorithm for inter-company relations at industrial markets. When selecting a partner company V.M. Sannikov [12] relies on "classical approach to analyzing the factors that affect business structure at the macro- and meso-levels, as well as further analysis of the organization's strengths and weaknesses".

Such foreign economists as D.L. Birch, J.A. Schumpeter, and R.K. Grunwald [13,14] have focused on the studies of HGC phenomenon. In Russian academic practice, Yu.A. Polunin, A.Y. Yudanov [15], D.S. Medovnikov, S.D. Rozmirovich, T. K. Oganesyan, A.N. Dolgin, N.M. Semenova [16,17] made a huge contribution to HGC studies.

This work consists of three related blocks, sequentially examining how the best partner company is selected and how to choose the best mode of interaction to achieve major industrial companies' development priorities : High-Growth Companies eligibility indicators, HGC partnership 
eligibility criteria, forms of strategic partnerships and their effects.

\section{METHODS}

\subsection{General Algorithm}

Achieving the development priorities of major industrial enterprises (MIE) through the use of strategic interaction with HGC calls for development of tools to identify a partner company for implementing strategic partnership mechanism. The proposed algorithm of selecting HGC as a MIC development method encompasses three consecutive stages:

Stage 1. A set of companies related to HGC stage is formed. Stage 2. Selection of companies by development trends.

Stage 3. The option card is formed, a partner company is identified, partnership agreement is made.

The first algorithm stage consists in forming the aggregate of High-Growth Companies on the basis of specific eligibility criteria as indicated in table 1 of this paper.

At the second algorithm stage, we indicate the major industrial companies (MIC)' development trends that could be implemented through MIC-HGC strategic partnership. Based on the analysis of RF major industrial companies' strategic objectives, three development trends have been identified. HGC as a strategic partner could lend itself as a major tool to meet MIC strategic objectives if it follows the said trends. [18]:

— Technological leadership;

- Import substitution;

- Business diversification.
At the third stage, a HGC option card for strategic partnership with the MIC is being developed. We suggest that managerial decision should be made on the basis of the option card based on comparing a partner company's performance indicator. The said indicator characterizes the specific features of High Growth Company and the changes in the value of a major industrial enterprise in the outcome of such partnership.

\subsection{High Growth Company Eligibility Criteria (Phase 1)}

Currently, there are five projects of assessing and identifying $\mathrm{HGC}$ in the RF. Based on the results of "TechSuccess" (TekhUspekh) (RVC JSC, NRU HSE, PwC) [19], a government project has been launched to support National Champions HGC. Depending on the project implementation conditions and target settings, approaches to HGC assessment differ as well. This factor hinders company selection. Although HGC are represented by companies of different time-period of market presence, number of employees and economic turnover on the Russian market, they have a number of common characteristics.

For academic purposes, we suggest that HGC be considered as the companies of a certain lifecycle stage, that of accelerated growth stage. This stage is characterized by economic turnover growth, meanwhile the companies demonstrate positive performance, and positive results of innovative activity. Any company can evolve into this stage at different time-periods, and either maintain and build up accelerated growth, or follow generally accepted life-cycle development pattern.

Table 1 High-Growth company eligibility criteria

\begin{tabular}{|l|l|}
\hline \multicolumn{1}{|c|}{ Criterion } & Criterion Value \\
\hline Age of the company & At least 4 years \\
\hline Average number of employees & At least 50 persons for the reporting period \\
\hline Average annual revenue growth rate & At least 20\% annually in the last three years \\
\hline Gross profit value & Positive value for the reporting period and 3 years earlier \\
\hline Value of intangible assets & At least 1.2 mln rubles for the reporting period \\
\hline Revenue value. & At least RUB 120 mln. for the reporting period \\
\hline Average annual growth rate of equity capital & Positive annual value for the last 3 years \\
\hline Property relations in the company & The company is not under the control of strategic investors of foreign countries \\
\hline
\end{tabular}

Within the study framework, we have highlighted the main shortcomings inherent to major HGC Russian ratings : Gazelle Business' [20], TechSuccess [19], RBC Rating: 50 most HGC of Russia [21], "Russian gazelles" [22].

- lack of resulting performance indicators accounting at the companies [19-22];

- availability of not freely accessible indicators in the rating [19];

- designing ratings based on personal data of companies, that could entail subjectivity in estimates [19, 20, 22];

- restriction of sampling by companies submitting personal data [19, 20, 22].
Based on the indicated weaknesses, we have formulated the main requirements for the HGC eligibility criteria:

1. The applied criteria should rule out subjective evaluation;

2. Criteria evaluation data should refer to available data, including those available in paid information systems;

3. The criteria evaluation data should refer to official data;

4. Criteria should not be industry - specific;

5. Criteria should evaluate both relative and absolute parameters, including the company's resulting performance criteria. 
So, within the framework of our study we have suggested the following criteria should be used to identify companies at the accelerated growth stage, as shown in table 1.

The suggested criteria system enables selecting companies from the whole array of registered RF entities on the basis of free data placed in information systems.

\subsection{Forms of Strategic Partnership}

In the paper we suggest a "Major Industrial Company High-Growth Company partnership" concept be considered as a mode of cooperation based on voluntary participation. It is basically aimed at achieving such strategic development trends as [18]: technological leadership, import substitution, business diversification.

From the HGC viewpoint, strategic partnership allows to overcome existing barriers to development and gain additional opportunities in the following development blocks:

- obtaining additional funding;

- entry into new markets, including geographical markets; - obtaining guaranteed sales volumes through being involved into an integrated chain of a major industrial company;

— holding joint $\mathrm{R} \& \mathrm{D}$, ranging from development arrangements in one or related fields and ending with the creation of joint $R \& D$ ventures;

— access to the material and technical base of a major industrial enterprise;
- an option to outsource a part of administrative functions to MIE (e.g., accounting, IT functions, etc.);

- use of management experience at the enterprise in the conditions of accelerated scaling of HGC activities.

Regarding that, it is noteworthy that the form of strategic partnership stipulates 3 options:

— making a partnership contract;

- purchase of a share in HGC by MIE.

- Establishment of a joint venture.

\subsection{Selecting Companies That Are Eligible for Partnership (steps 2, 3)}

It is also noteworthy that the algorithm has enabled to examine several trends: the choice of HGC to achieve one development trend by MIE or eligibility of HGC to several development trends simultaneously. Selection criteria of HGC for eligibility to strategic development trends of MIC have been highlighted in Table 3 .

We suggest the values of industry average indicators by company's return rate groups should be determined on the basis of the Return Rate (RR) by economic activity types indicated by the RF Federal Tax Service (FTS). As a result of such an assessment, aggregates of companies are formed with a glance to their strategic development trends. Thus, based on the results, seven groups of companies shown in figure 1 could be formed.

Table 3 HGC selection criteria by development trends

\begin{tabular}{|c|c|}
\hline Criterion & Criterion Value \\
\hline \multicolumn{2}{|r|}{ Technological leadership; } \\
\hline Type of activity & Relevance to selected activity/industry \\
\hline Obtaining a competitive advantage & $\begin{array}{l}\text { Company's eligibility to at least one of the following provisions: } \\
\text { - obtaining access to new markets or increasing the market share occupied by the decision- } \\
\text { making company; } \\
\text { - reduction of costs in product/implementation of decision-making company's technology; } \\
\text { - reduction of decision-making company's administrative costs; } \\
\text { - improving decision-making company's reputation. }\end{array}$ \\
\hline Value of intangible assets & At least $5 \%$ of revenue \\
\hline \multicolumn{2}{|r|}{ Import substitution; } \\
\hline Type of activity & Relevance to selected activity/industry \\
\hline $\begin{array}{l}\text { Indicating the degree of product/technology } \\
\text { availability and the proportion of materials } \\
\text { and components in the finished product }\end{array}$ & $\begin{array}{l}\text { The extent of HGC technology availability level to share of materials and components in the } \\
\text { finished product }\end{array}$ \\
\hline \multicolumn{2}{|r|}{ Business diversification. } \\
\hline Type of activity & Relevance to selected activity/industry \\
\hline Company's liquidity indicators. & $\begin{array}{l}\text { Within this group, the following indicators are evaluated: } \\
\text { - Fast liquidity ratio (FLR) - more than } 1.0 \\
\text { - current liquidity ratio (CLR) - more than } 2.0 \\
\text { - absolute liquidity ratio (ALR) - more than } 0.2\end{array}$ \\
\hline ROI indicators of the company. & $\begin{array}{l}\text { Within this group, the following indicators are evaluated: } \\
\text {-profit margin }(\mathrm{Pm}) \text { and return of assets }\left(\mathrm{R}_{\mathrm{a}}\right) \text { - not less than the industry average }\end{array}$ \\
\hline The growth rate of the "Revenue" indicator & $\mathrm{GR}_{\mathrm{T}}$ - not less than $30 \%$ \\
\hline
\end{tabular}




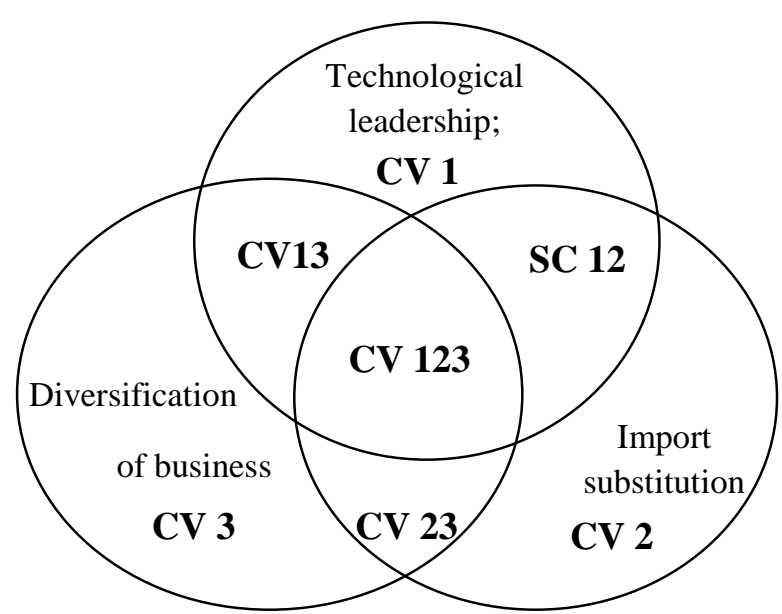

Figure 1 Company aggregates by strategic development trends.

Apart from HGC specific features, to calculate a partner company's integral performance indicator, a researcher should examine the extent to which strategic partnership meets the development goals along the development trend selected by the MIC. Thus, two or three goals are calculated for each HGC selected along the so chosen development trend. Regarding Business diversification case, performance indicators of a partner company are calculated according to formula 1

PE $=$ IIn x DGI (1)

where IIn stands for normalized integral indicator;

DGI stands for Development goal indicator

Development goals indicator is determined by the expert person who makes a decision on strategic partnership, according to table 4 .

\section{Table 4 Indicator of meeting the development trend goals}

\begin{tabular}{|c|l|}
\hline Range & \multicolumn{1}{|c|}{ Characteristic } \\
\hline$<0.25$ & Small contribution \\
\hline $0.25 \ldots$ & Moderate contribution \\
0.5 & \\
\hline $0.5 \ldots 0.75$ & Significant contribution \\
\hline$>0.75$ & Top Contribution \\
\hline
\end{tabular}

The recommended ranges have been determined on the basis of a survey conducted by researchers in the field of MIE strategic development, and industrial companies' decision-makers. The said value ranges have been tested for convergence. HGC integral indicator is calculated as the sum of normalized indicators for individual development trends adjusted for their weight.

$\mathrm{II}=\boldsymbol{\Sigma}\left(\mathrm{II}_{\mathrm{T}} \mathrm{x} \mathrm{IIW}_{\mathrm{T}}+\mathrm{II}_{\mathrm{I}} \mathrm{x} \mathrm{IIW}_{\mathrm{I}}+\mathrm{II}_{\mathrm{D}} \mathrm{x} \mathrm{IIW}_{\mathrm{D}}\right)(2)$

where $\mathrm{II}_{\mathrm{T}}, \mathrm{II}_{\mathrm{I}}, \mathrm{II}_{\mathrm{D}}-$ an integral indicator for the relevant strategic development trend "Technological leadership", "Import substitution", "Business diversification";

$\mathrm{IIW}_{\mathrm{T}}, \quad \mathrm{IIW}_{\mathrm{I}}, \mathrm{IIW}_{\mathrm{D}}-$ weight of the integral indicator according to the corresponding strategic development trend.
The weight of strategic development trend is defined as components of the normalized vector of priorities.

Further, the integral indicators are normalized within the set of selected HGC in the selected development trend.

The integral indicator regarding the Technological leadership" strategic development trend is accepted by formula (3) and is streamlined in several stages.

$\mathrm{II}_{\mathrm{T}}=\mathrm{CAnw}+\mathrm{IANnv}$

where CAnw stands for the normalized value according to the "Competitive advantage" criterion. The said value is determined based on the value of the normalized vector of competitive advantage priorities met by a partner company. If a company meets several competitive advantages, the criterion value is determined by summing the normalized priority vectors for the selected competitive advantages;

IANnv - the normalized value according to the "Share of intangible assets" criterion. The share of intangible assets in the balance sheet structure is determined by dividing the value of intangible assets (IA) by the total value of assets of the enterprise.

At the first stage, the decision maker prioritizes the acquisition of different types of competitive advantages. To form the priority, the author suggests the Saati paired comparison method be applied using the fundamental scale of absolute numbers. The scale ranges from no-preference option (degree of preference equal to 1), i.e. the same alternatives in terms of achieving the goals set, up to the absolute preference (the degree of preference equal to 9). It means that a certain alternative is much more effective than another in terms of objectives fulfillment [23]

The matrix of the pairwise comparison is given in Table 5 . At the same time, when performing pair-wise comparisons, it is recommended to use the following questions:

- Which competitive advantage is more important or has a greater impact on the company development strategic goal achievement?

- Which competitive advantage is preferred to achieve the strategic goal of the company's development?

\section{Table 5 Competitive Advantage Comparison Matrix}

\begin{tabular}{|c|c|c|c|c|}
\hline $\begin{array}{c}\text { Competitive } \\
\text { advantages }\end{array}$ & $\begin{array}{c}\text { CA } \\
1\end{array}$ & CA 3 & CA 3 & CA 4 \\
\hline CA 1 & $\mathrm{a}_{11}$ & $\mathrm{a}_{12}$ & $\mathrm{a}_{13}$ & $\mathrm{a}_{14}$ \\
\hline CA 2 & $\mathrm{a}_{21}$ & $\mathrm{a}_{22}$ & $\mathrm{a}_{23}$ & $\mathrm{a}_{24}$ \\
\hline CA 3 & $\mathrm{a}_{31}$ & $\mathrm{a}_{32}$ & $\mathrm{a}_{33}$ & $\mathrm{a}_{34}$ \\
\hline CA 4 & $\mathrm{a}_{41}$ & $\mathrm{a}_{42}$ & $\mathrm{a}_{43}$ & $\mathrm{a}_{44}$ \\
\hline
\end{tabular}

CA1 - obtaining access to new markets or increasing the market share occupied by the decision-making company;

CA2 - reduction of costs in product/implementation of decision-making company's technology.

CA3 - a decrease in administrative costs of a decision-making company;

CA4 - improving the reputation of the decisionmaking company. 
It is also recommended to calculate the consistency ratio and, if the value does not exceed $10-15 \%$, the resulting value is counted as a competitive advantage score.

The next step is determined by the "Share of intangible assets in the balance sheet structure" criterion. For this purpose, the values of indicators are normalized according to the formula 4.

$$
\mathrm{Xn}=\mathrm{Xf} / \mathrm{Xmax}
$$

where $\mathrm{Xn}$ stands for the normalized value of the indicator; $\mathrm{Xf}$ stands for the actual value of the indicator

$\mathrm{Xmax}$ is the maximum factor value

The normalized value of the indicator is taken into account as a score while calculating the integral indicator along “Technological leadership" strategic development trend.
The integral indicator for the "Import substitution" strategic development trend is calculated on the basis of a scoring/ rating system, taking into account the selection criteria used while forming the aggregate of companies. The scoring system is shown in table 6.

Scores are set based on the ratio of the readiness level of the technology and the share of materials and components in the finished product. The higher the technology readiness level and the greater share of materials and components in the finished product, the higher score should be awarded to the partner company.

\section{Table 6 Scoring system for the "Import substitution" strategic development trend}

\begin{tabular}{|c|c|c|c|c|c|c|c|c|c|}
\hline $\begin{array}{c}\text { Share of materials and } \\
\text { components in finished } \\
\text { products }\end{array}$ & \multicolumn{9}{|c|}{ Technology readiness level. } \\
\cline { 2 - 11 } & TRL1 & TRL2 & TRL3 & TRL4 & TRL5 & TRL6 & TRL7 & TRL8 & TRL9 \\
\hline$<5 \%$ & - & - & - & - & - & - & - & - & 1 \\
\hline $5 \%-10 \%$ & - & - & - & - & - & - & - & 1 & 2 \\
\hline $10 \%-20 \%$ & - & - & - & - & - & - & 1 & 2 & 3 \\
\hline $20 \%-30 \%$ & - & - & - & - & - & 1 & 2 & 3 & 4 \\
\hline $30 \%-40 \%$ & - & - & - & - & 1 & 2 & 3 & 4 & 5 \\
\hline $40-50 \%$ & - & - & - & 1 & 2 & 3 & 4 & 5 & 6 \\
\hline $50 \%-70 \%$ & - & - & 1 & 2 & 3 & 4 & 5 & 6 & 7 \\
\hline $70 \%-85 \%$ & - & 1 & 2 & 3 & 4 & 5 & 6 & 7 & 8 \\
\hline$>85 \%$ & 1 & 2 & 3 & 4 & 5 & 6 & 7 & 8 & 9 \\
\hline
\end{tabular}

The integral indicator along the "Diversification of business" strategic development trend is formed summing the normalized indicators based on selection criteria while forming an aggregate of companies.

$\mathrm{II}_{\mathrm{D}}=\mathrm{PM}_{\mathrm{n}}+\mathrm{R}_{\mathrm{ALN}}+\mathrm{GR}_{\mathrm{n}}$ (5)

Where $\mathrm{PM}_{\mathrm{n}}$ stands for the normalized profit margin.

$\mathrm{R}_{\mathrm{ALN}}$ stands for normalized ratio of absolute liquidity

GR $n$ stands for normalized growth rate of "Revenue" indicator

The next step of forming the partner company's option card is to assess the economic effect of strategic partnership mechanism implementation, which is assessed through the change in the cost of the MIE.

The basic business valuation methods were analyzed for selecting a method of MIE evaluation. The authors suggest profit/ income approach should be applied, in particular, the profit (income) capitalization method, since on the one hand the information regarding this method is freely available, on the other hand, this method allows taking the industry- and company-related risks into consideration.

$\triangle \mathrm{CV}=\mathrm{CV}_{\mathrm{EV}}-\mathrm{CV}_{\mathrm{b}}(6)$

where $\triangle \mathrm{CV}$ stands for change in the cost of the MIE CVEV , CVb stand for MIE cost while implementing strategic partnership mechanism and in the basic variant, respectively.

$\mathrm{CV}=\mathrm{NP} / \mathrm{R}-\mathrm{g}$ $\mathrm{g}$ stands for projected average growth rate of the company profit.

The discount rate is determined by the cumulative method and is based on the assessment of the following factors:

1. Quality of enterprise management.

2. The size of the enterprise.

3. Finance.

4. Commodity diversification of the enterprise.

5 . The degree of diversification of the clientele.

6 . The level and predictability of profits.

7. Other risks, including country risk, technology dependency risk, etc.

The next step to form a choice card of the partner company is to rationalize the change in the MIE cost.

Company's option card is formed by applying the values of the efficiency indicator of a partner company and changes in the cost of MIE on the schedule (Figure 2).

The most attractive partner company in this way will be a company that satisfies the following conditions:

$\mathrm{PE} \longrightarrow \max$

$\triangle \mathrm{CVn} \longrightarrow \max (8)$,

where I PEN stands for the value of the partner company's performance indicator;

$\Delta \mathrm{CVn}$ stands for normalized value of the change in the value of the MIE.

Where NP stands for net profit;

$\mathrm{R}$ stands for discount rate; 


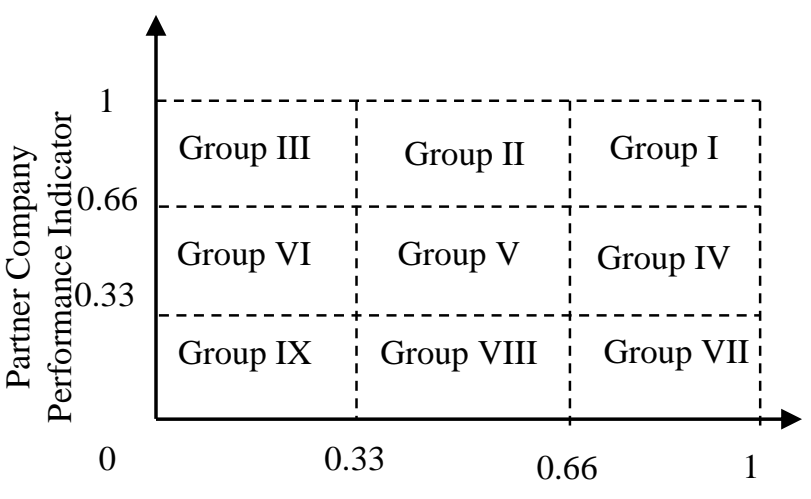

The normalized value of the change in the MIE estimate value.

Figure 2 Formation of the Partner Company Option card

Prioritization order of partner company selection based on the option card in transactions is given in Table 9.

\section{Table 7 Partner Selection Priorities Based on Option} card

\begin{tabular}{|c|c|}
\hline Priority & Groups \\
\hline High & I, II, IV \\
\hline Medium & III, V, VI \\
\hline $\begin{array}{c}\text { The lowest not } \\
\text { recommended for } \\
\text { transaction) }\end{array}$ & VII, VIII, IX \\
\hline
\end{tabular}

At the final milestone negotiations with the partner company are held and arrangements are made. If no arrangement with the priority company has been reached during the negotiations, it is highly recommended to start negotiations with the company assigned to the same (if any) priority group or to the next priority group.

\section{RESULTS}

At the first stage of testing the proposed algorithm based on SPARK-Interfax information disclosure system, all the companies operating on the territory of the Russian Federation have been analyzed. Using high-growth companies eligibility criteria, 60 companies were selected. Analyzing the obtained sample, it is possible to conclude that major companies (34 companies out of 60) that predominate in high-growth companies. The largest concentration of companies is observed in the Central Federal District. In terms of industry, 38\% of companies falls on the manufacturing industry. At the second stage of the algorithm, in accordance with the chosen development trend, we selected High-Growth Companies into the "Business Diversification" aggregate. The qualification was passed by 2 companies out of the analyzed 60 (less than 5\%). First of all, this is conditioned by the limitation of sample by company activity sphere - mining, manufacturing sectors, professional, academic and technical activities were considered as highly prioritized. This factor has reduced the original number of analyzed companies from 60 by 30. Further, indicators of the main activity of the companies were analyzed, which left 2 companies in the final sample of HGC: JSC "NPP Burevestnik", leading R\&D in the field of natural and technical sciences with annual revenue of 1878 million rubles and LLC "Perm Chemical Company", an enterprise engaged in production of other basic inorganic chemicals with annual revenue of RUB 1791.36 million.

3.89 million commercial enterprises in the territory of the Russian Federation

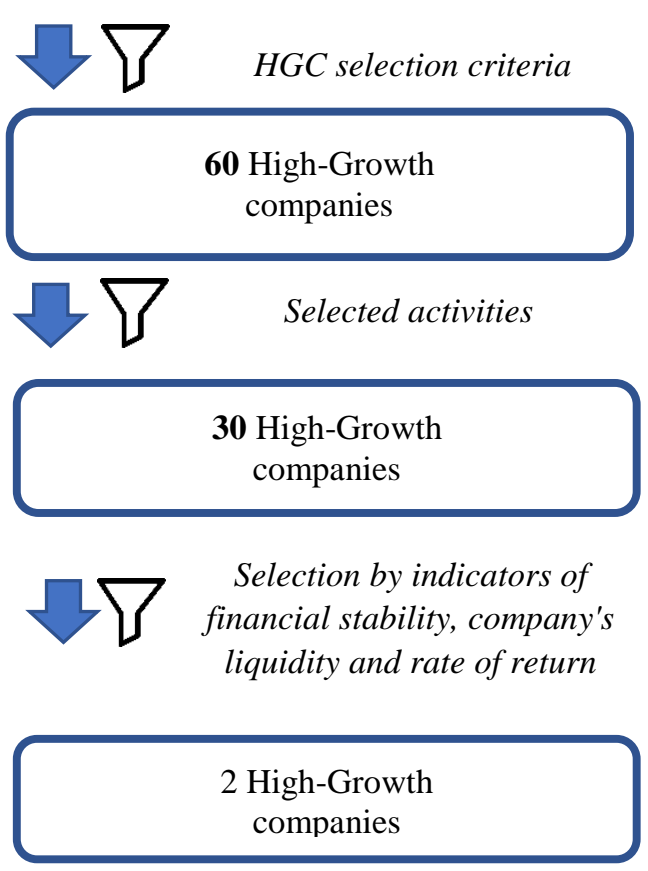

Figure 3 Sampling volume and dynamics when applying the proposed algorithm

As a result, partner company's option card was formed (Table 8).

Table 8 Formation of the Partner Company Option card

\begin{tabular}{|c|c|c|c|c|}
\hline Name full & $\begin{array}{c}\text { PE, } \\
\text { share } \\
\text { unit }\end{array}$ & $\begin{array}{c}\Delta C V, \\
\text { RUB } \\
\text { billion }\end{array}$ & $\begin{array}{l}\Delta \mathrm{CV}_{\mathrm{n},} \\
\text { share unit }\end{array}$ & Group \\
\hline \multicolumn{5}{|c|}{ LLC "Perm Chemical Company" } \\
\hline $\begin{array}{l}\text { Buying a } \\
\text { share of the } \\
\text { company }\end{array}$ & 0.6 & $\begin{array}{c}179.6 \\
5\end{array}$ & 0.37 & V \\
\hline $\begin{array}{l}\text { Establishment } \\
\text { of a joint } \\
\text { venture. }\end{array}$ & 0.8 & $\begin{array}{c}483.4 \\
3\end{array}$ & 1 & I \\
\hline \multicolumn{5}{|c|}{ JSC "Research and Production Enterprise "Burevestnik" } \\
\hline $\begin{array}{l}\text { Buying a } \\
\text { share of the } \\
\text { company }\end{array}$ & 0.21 & 87.75 & 0.18 & IX \\
\hline $\begin{array}{l}\text { Establishment } \\
\text { of a joint } \\
\text { venture. }\end{array}$ & 0.49 & $\begin{array}{c}135.0 \\
0\end{array}$ & 0.28 & IX \\
\hline
\end{tabular}

On the basis of the obtained data, the company belonging to the I group, "PCK" LLC, has the top priority. Establishment of a 
[10] O.K. Shinkevich. Assessment of industrial

joint venture is a recommended form of strategic partnership. In case of failure to reach agreements following the results of negotiations between the MIC and HGC it is recommended to pay attention to the share purchase option of HGC.

\section{REFERENCES}

[1] I. Stepnov, Yu. Kovalchuk (2018). Value Chain Modeling in Digital Strategic Management. Accounting. Analysis. Auditing. 5. 6-23. DOI: 10.26794/2408-93032018-5-5-6-23.

[2] A.A. Govorin, A.V. Kostin. Actual goals and objectives of strategic development of domestic industry. Statistics and Economics. 2017;(3):41-47. (In Russ.) DOI: https://doi.org/10.21686/2500-3925-2017$3-41-47$

[3] J. Ramanauskas, I. Sergeyev, T. Ponomarenko. (2014). Large Mineral and Chemical Companies and their Reaction to Calls of Global Economy. Verslas: teorija ir praktika. 15. 103-113. 10.3846/btp.2014.10.

[4] O. K. Dorozhkina. Strategic Planning of Innovation Development at Industrial Enterprises. Rossiyskoe predprinimatelstvo. 2011. 12(1). 83-88. (in Russian)

[5] J. Kovalchuk, I. Stepnov. Research of the technological future's uncertainty. MGIMO Review of International Relations. 2019. vol. 12. No 6. P. 214-224. DOI: $10.24833 / 2071-8160-2019-6-69-214-224$

[6] V. S. Litvinenko, I. B. Sergeev. Innovations as a Factor in the Development of the Natural Resources Sector. Studies on Russian Economic Development. 2019. Vol. 30. No 6. pp. 635-643. DOI: $10.1134 / \mathrm{S} 107570071906011 \mathrm{X}$

[7] V. Litvinenko. Digital Economy as a Factor in the Technological Development of the Mineral Sector. Natural Resources Research. 2019. DOI: 10.1007/s11053-019-09568-4

[8] N. Grankina. Strategija vybora partnerov po kanalu sbyta. [Strategy for selecting sales channel partners]. (in Russian). Available at: https://www.marketing.spb.ru/lib$\underline{\mathrm{mm} / \mathrm{sales} / \mathrm{sales} \text { part_select.htm }}$

[9] D. H. Maister Razrabotka sistemy upravlenija partnerstvom. [The development of the partnership management system] (in Russian). Available at: https://www.cfin.ru/management/strategy/orgstr/partner ship.shtml enterprise for the purposes of its innovative development. Creative economy. 2010. 3. 37-44. (in Russian).

[11] Yu.F. Popova. Capital of Interfirm Relationships: The Concept and Evaluation Methodology. Upravlenets - The Manager. 2017. no. 4(68). pp. 32-38.

[12] V.M. Sannikov. Metodika podgotovki koncepcii vzaimodejstvija partnerov po strategicheskomu al'jansu. [Methodology for the cooperation between partners in a strategic alliance preparing concept]. Menedzhment segodnja [Management today].2016. No1.32-40. (in Russian).

[13] D.L. Birch, J. Medoff. Gazelles. In Lewis C.Solomon and Alec R. Levenson, eds., Labor Markets, Employment Policy, and Job Creation. Boulder: Westview Press, 1994. pp. 159-168.

[14] R. Gruenwald. (2014). Shaping policy supporting high-growth entrepreneurship: Reflections on EU SME policy. Horyzonty Polityki. Vol. 5. No. 10. pp. 105 126.

[15] A.Y. Yudanov, A.A. Yakovlev. 'Unorthodox' fastgrowing firms (gazelles) and North's limited access order. Voprosy Ekonomiki. 2018;(3):80-101. (In Russ.). DOI: https://doi.org/10.32609/0042-8736-2018-3-80101

[16] D. Medovnikov, S. Rozmirovich, (2019). Export and Change Yourself: Key Challenges for Fast-growing Technology Companies in Russia. The world of new economy. 13. 6-22. DOI: 10.26794/2220-6469-201913-2-6-22.

[17] D. Medovnikov, T. Oganesyan, S. Rozmirovich Candidates for the championship: Medium-sized high growth companies and state-run programs for their support. Voprosy Ekonomiki. 2016;(9):50-66. (In Russ.) DOI: https://doi.org/10.32609/0042-8736-20169-50-66

[18] E. Byl. Improvement of the mechanism of development large industrial companies. Economics and management: research and practice journal. 2018. 2 (140). 131-136. . (in Russian).

[19] TechUp: Russia`s fast-growing high-tech companies national rating. Available at: http://ratingtechup.ru/en/about/

[20] Rating «Gazelle of Business» (in Russian). Available at: https://www.dp.ru/g/ 
[21] Rejting RBK: 50 samyh bystrorastushhih kompanij Rossii [RBC Rating: 50 fastest growing companies in Russia]. (in Russian). Available at: https://www.rbc.ru/business/31/10/2019/5db6f6a19a79 $476 \mathrm{eb} 64 \mathrm{e} 7 \mathrm{e} 51$

[22] Rejting «Russkie gazeli» [Rating «Russian gazelles»]. (in Russian). Available at: https://expert.ru/dossier/story/fastest-growingcompanies-gazelles/

[23] T. L. Saaty. Axiomatic Foundation of the Analytic Hierarchy Process. Management Science. 1986. Vol. 32, Issue 7. - P. 841-855. DOI: 10.1287/mnsc.32.7.841 